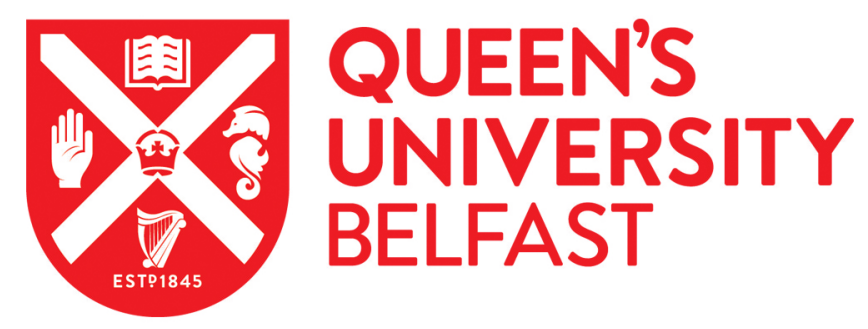

\title{
Mating Type and Aggressiveness of Phytophthora infestans (Mont.) de Bary in Potato-Growing Areas of Punjab, Pakistan, 2017-2018 and Identification of Genotype 13_A2 in 2019-2020
}

Raza, W., Ghazanfar, M. U., Sullivan, L., Cooke, D. E. L., \& Cooke, L. R. (2020). Mating Type and Aggressiveness of Phytophthora infestans (Mont.) de Bary in Potato-Growing Areas of Punjab, Pakistan, 2017-2018 and Identification of Genotype 13_A2 in 2019-2020. Potato Research.

https://doi.org/10.1007/s11540-020-09467-9

\section{Published in:}

Potato Research

\section{Document Version:}

Publisher's PDF, also known as Version of record

Queen's University Belfast - Research Portal:

Link to publication record in Queen's University Belfast Research Portal

\section{Publisher rights}

Copyright 2020 the authors.

This is an open access article published under a Creative Commons Attribution License (https://creativecommons.org/licenses/by/4.0/), which permits unrestricted use, distribution and reproduction in any medium, provided the author and source are cited.

\section{General rights}

Copyright for the publications made accessible via the Queen's University Belfast Research Portal is retained by the author(s) and / or other copyright owners and it is a condition of accessing these publications that users recognise and abide by the legal requirements associated with these rights.

Take down policy

The Research Portal is Queen's institutional repository that provides access to Queen's research output. Every effort has been made to ensure that content in the Research Portal does not infringe any person's rights, or applicable UK laws. If you discover content in the

Research Portal that you believe breaches copyright or violates any law, please contact openaccess@qub.ac.uk. 


\title{
Mating Type and Aggressiveness of Phytophthora infestans (Mont.) de Bary in Potato-Growing Areas of Punjab, Pakistan, 2017-2018 and Identification of Genotype 13_A2 in 2019-2020
}

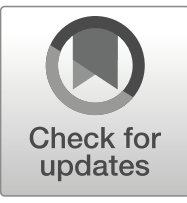

\author{
Waqas Raza ${ }^{1}$ - Muhammad Usman Ghazanfar ${ }^{1}$ - Louise Sullivan ${ }^{2}$ • \\ David E. L. Cooke ${ }^{2}$ - Louise R. Cooke ${ }^{3}$ (D)
}

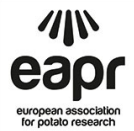

Received: 23 August 2019 / Accepted: 17 July 2020 /

Published online: 18 August 2020

(C) The Author(s) 2020

\begin{abstract}
Samples of blighted potato leaves were collected from fields in six potato-growing districts of the Punjab Province of Pakistan in 2017-2018. A total of 149 isolates of Phytophthora infestans were obtained from six potato cultivars (Asterix, Barsenna, Burana, Caroda, Mazika, Sante). Of these isolates, $73 \%$ were A1 mating type, 23\% were A2 mating type and $4 \%$ were self-fertile. Both mating types of $P$. infestans occurred in all six districts sampled, but in every case, the A1 mating type predominated. The foliar aggressiveness of 104 of these isolates (weakly pathogenic isolates were excluded) was tested on detached leaflets of potato cv. Caroda, and a composite aggressiveness index (CAI) calculated from lesion area (measured after 10 days), latent period and infection frequency was used to compare isolates. There was no difference in CAI between isolates obtained from different districts or cultivars. The A2 mating type isolates had significantly greater CAIs than A1 isolates but this does not imply a genetic linkage nor a general association between mating type and aggressiveness. It may be that the A2 isolates belonged to an aggressive clonal lineage such as 13_A2 that has been reported in other countries in the region. While it was not possible to test the isolates collected in 2017-2018, genotyping of samples collected in 2019-2020 showed the widespread occurrence of the EU_13_A2 clonal lineage in the same districts of Pakistan and supported this hypothesis. This is the first report of EU_13_A2 from Pakistan. The implications for potato late blight management in the Punjab are discussed.
\end{abstract}

Keywords Aggressiveness $\cdot$ Late blight $\cdot$ Mating type $\cdot$ Phytophthora infestans population

Waqas Raza

waqasraza61@yahoo.com

Louise R. Cooke

1.cooke@qub.ac.uk

Extended author information available on the last page of the article 


\section{Introduction}

Potato (Solanum tuberosum L.) is the most important vegetable crop worldwide and the third most important food crop after wheat and rice (Jansky et al. 2019); its tubers are a globally important dietary source of starch, protein, antioxidants and vitamins (Burlingame et al. 2009). Potatoes grow in a wide range of habitats from sea level to $4000 \mathrm{~m}$ altitude and from $47^{\circ} \mathrm{S}$ to $65^{\circ} \mathrm{N}$ latitude (Hijmans 2001). While potato consumption has been declining in Europe and North America, it has been steadily increasing in the developing world; now, more potato production takes place in developing countries than in the developed world and potatoes have an important role in food security of developing countries (Wijesinha-Bettoni and Mouillé 2019). Late blight of potato caused by Phytophthora infestans (Mont.) de Bary is the most devastating disease affecting the crop worldwide in terms of both quality and quantity of yield (Nowicki et al. 2012). It is one of the main limiting factors for potato production in the world, and if the disease is not controlled, losses can reach $100 \%$ (Ghorbani et al. 2004), and even with low infection levels, the crop may be unsuitable for storage (Fernández-Northcote et al. 2000).

$P$. infestans is a heterothallic oomycete with two mating types, A1 and A2. Until the 1980s, the A2 mating type had been found only in Mexico where Gallegly and Galindo (1958) showed that both mating types were present; elsewhere, only the A1 mating type had been identified. The A2 mating type was first reported outside Mexico by Hohl and Iselin (1984), and now, both mating types occur in most potato-producing regions worldwide (Fry et al. 2015). Where both mating types are present in the same field, sexual recombination may occur resulting in formation of sexual oospores which can survive in soil for several years (Turkensteen et al. 2000), cause early infections and affect the population structure (Fry 2008). Sexual recombination can lead to greater variability, rendering the population more adaptable and generating more aggressive genotypes, which may be fungicide-resistant (Drenth et al. 1993; Cooke et al. 2012). However, the presence of both mating types does not necessarily result in the pathogen population reproducing sexually, although it is obviously a prerequisite. $P$. infestans may reproduce predominantly clonally even if both mating types are present: two or more separate clonal lineages may exist in parallel, surviving on potato tubers during the winter, as when there was only a single mating type (Yuen and Andersson 2013).

Potatoes are a significant crop in Pakistan; in 2018, the annual production was about 4.58 million tonnes on about 0.20 million hectares (Pakistan Economic Survey 2018-19 2019). The first report of late blight in Pakistan was from the Swat District (Khan et al. 1985), and it has since been found in the plains of the Punjab, the North-West Frontier Province (NWFP), Baluchistan and northern Pakistan. Ahmad and Mirza (1995) first identified the A2 mating type of $P$. infestans in Pakistan when they tested 45 isolates collected in 1994 from potato-growing areas of the Punjab and the NWFP and found that $49 \%$ were A2, while the remainder were A1. Subsequently, 281 isolates collected over 3 seasons between 1997 and 2000 were tested and both mating types were found in all areas except the lower valleys of the NWFP where only A1 was detected; the A1 mating type predominated in all years, but self-fertile isolates were also found in 1999-2000 (Ahmad et al. 2002). A further 178 isolates collected from the potato-growing areas of Pakistan in the Punjab, the Swat valley and the Upper Swat valley were tested for metalaxyl resistance and mating type (Ahmad et al. 2008); metalaxyl resistance occurred 
among both A1 and A2 isolates except in the Upper Swat valley where resistance occurred only in the A1 population. In the last 10 years, there has been little published information on the population structure of $P$. infestans in Pakistan and it is unclear if the pathogen is sexually reproducing, although Ahmad et al. (2002) noted the presence of both mating types within a single field. As late blight of potato is an important threat to potato production in Pakistan and the occurrence together of the two mating types of $P$. infestans potentially impacts on disease management, an extensive study of their incidence in the Punjab, where over 95\% of Pakistan's potatoes are produced, was initiated. The foliar aggressiveness of selected isolates of $P$. infestans was investigated. Genotyping of the 2017-2018 isolates using the SSR markers which have been applied to $P$. infestans populations worldwide ( $\mathrm{Li}$ et al. 2013) to elucidate further the structure of the pathogen population in Pakistan was unfortunately not possible, but samples of $P$. infestans DNA were collected in the same region in 2019-2020 and genotyped.

\section{Materials and Methods}

The research was conducted in the laboratory of Plant Pathology, College of Agriculture, University of Sargodha, Sargodha, Punjab, Pakistan during 2017-2020.

\section{Sample Collection and Isolation of Phytophthora infestans}

Leaves with the characteristic symptoms of late blight were collected from infected potato crops during field visits to potato-producing areas of the Punjab, Pakistan, in 2017 and 2018 (Table 1). Two methods were used to isolate $P$. infestans into agar culture. In the first, blighted leaves were incubated overnight in humid boxes at 15$20{ }^{\circ} \mathrm{C}$ to encourage sporulation. When sporulation had developed, P. infestans was isolated by picking off sporangia using small cubes of rye agar A (Caten and Jinks 1968) containing $200 \mathrm{mg}$ sodium ampicillin $\mathrm{L}^{-1}$ and $50 \mathrm{mg}$ rifampicin $\mathrm{L}^{-1}$ and placing the cubes onto antibiotic rye agar plates. The plates were incubated at $18{ }^{\circ} \mathrm{C}$ in darkness and checked regularly for growth of $P$. infestans hyphae under a low-power microscope. When colonies had developed, they were sub-cultured onto fresh antibiotic rye agar plates. Alternatively, sections of leaves with late blight lesions were placed under potato tuber slices (cut from surface-sterilised tubers) in Petri dishes sealed with parafilm and incubated at $18{ }^{\circ} \mathrm{C}$ for up to 7 days; sporulation usually developed on the upper surface of the slices in 3-4 days. Sporangia were then picked off using antibiotic rye agar cubes and isolated as described above. Sampling of late blight lesion DNA onto FTA cards according to the methods of Li et al. (2013) was conducted from potato crops in the same potato-producing areas in December 2019 and January 2020 (Table 2). The abaxial surfaces of four actively spreading foliar blight lesions per crop were pressed onto each FTA card, allowed to air dry and then each card stored individually in plastic bags for subsequent processing.

\section{Maintenance of Isolates}

Isolate cultures were maintained for periods of up to 6 months on 9-cm Petri plates using either rye agar A (Caten and Jinks 1968) or pea agar (Hollomon 1965). Cultures 
Table 1 Potato-growing areas of the Punjab, Pakistan, from which late blight samples were collected in 2017 and 2018

\begin{tabular}{|c|c|c|c|c|c|}
\hline District & Location name & Location & Year & Cultivar & No. of isolates obtained \\
\hline \multirow[t]{6}{*}{ Khushab } & Khushab & $32.2955^{\circ} \mathrm{N}, 72.3489^{\circ} \mathrm{E}$ & 2017 & Caroda & 3 \\
\hline & Khushab & $32.2955^{\circ} \mathrm{N}, 72.3489^{\circ} \mathrm{E}$ & 2018 & Caroda & 3 \\
\hline & Naushehra & $32.5641^{\circ} \mathrm{N}, 72.1594^{\circ} \mathrm{E}$ & 2017 & Barsenna & 4 \\
\hline & Naushehra & $32.5641^{\circ} \mathrm{N}, 72.1594^{\circ} \mathrm{E}$ & 2018 & Barsenna & 6 \\
\hline & Jauharabad & $32.2899^{\circ} \mathrm{N}, 72.2719^{\circ} \mathrm{E}$ & 2017 & Caroda & 3 \\
\hline & Jauharabad & $32.2899^{\circ} \mathrm{N}, 72.2719^{\circ} \mathrm{E}$ & 2018 & Caroda & 3 \\
\hline \multirow[t]{6}{*}{ Sargodha } & Sargodha & $32.0740^{\circ} \mathrm{N}, 72.6861^{\circ} \mathrm{E}$ & 2017 & Caroda & 3 \\
\hline & Sargodha & $32.0740^{\circ} \mathrm{N}, 72.6861^{\circ} \mathrm{E}$ & 2018 & Caroda & 3 \\
\hline & Shahpur & $32.2878^{\circ} \mathrm{N}, 72.4288^{\circ} \mathrm{E}$ & 2017 & Caroda & 4 \\
\hline & Shahpur & $32.2878^{\circ} \mathrm{N}, 72.4288^{\circ} \mathrm{E}$ & 2018 & Caroda & 4 \\
\hline & Sahiwal & $31.9765^{\circ} \mathrm{N}, 72.3282^{\circ} \mathrm{E}$ & 2017 & Caroda & 5 \\
\hline & Sahiwal & $31.9765^{\circ} \mathrm{N}, 72.3282^{\circ} \mathrm{E}$ & 2018 & Caroda & 5 \\
\hline \multirow[t]{6}{*}{ Sahiwal } & Chak Jeevan Shah & $30.6682^{\circ} \mathrm{N}, 73.1114^{\circ} \mathrm{E}$ & 2017 & Mazika & 3 \\
\hline & Chak Jeevan Shah & $30.6682^{\circ} \mathrm{N}, 73.1114^{\circ} \mathrm{E}$ & 2018 & Mazika & 3 \\
\hline & Saleem Kot & $30.3708^{\circ} \mathrm{N}, 73.2397^{\circ} \mathrm{E}$ & 2017 & Mazika & 4 \\
\hline & Saleem Kot & $30.3708^{\circ} \mathrm{N}, 73.2397^{\circ} \mathrm{E}$ & 2018 & Mazika & 4 \\
\hline & Chak Sundhey Khan & $30.6682^{\circ} \mathrm{N}, 73.1114^{\circ} \mathrm{E}$ & 2017 & Mazika & 6 \\
\hline & Chak Sundhey Khan & $30.6682^{\circ} \mathrm{N}, 73.1114^{\circ} \mathrm{E}$ & 2018 & Mazika & 7 \\
\hline \multirow[t]{6}{*}{ Okara } & Okara & $30.8138^{\circ} \mathrm{N}, 73.4534^{\circ} \mathrm{E}$ & 2017 & Sante & 4 \\
\hline & Okara & $30.8138^{\circ} \mathrm{N}, 73.4534^{\circ} \mathrm{E}$ & 2018 & Sante & 4 \\
\hline & Renala Khurd & $30.8782^{\circ} \mathrm{N}, 73.5954^{\circ} \mathrm{E}$ & 2017 & Sante & 4 \\
\hline & Renala Khurd & $30.8782^{\circ} \mathrm{N}, 73.5954^{\circ} \mathrm{E}$ & 2018 & Sante & 4 \\
\hline & Deepalpur & $30.6770^{\circ} \mathrm{N}, 73.6477^{\circ} \mathrm{E}$ & 2017 & Mazika & 6 \\
\hline & Deepalpur & $30.6770^{\circ} \mathrm{N}, 73.6477^{\circ} \mathrm{E}$ & 2018 & Mazika & 7 \\
\hline \multirow[t]{6}{*}{ Chiniot } & Chiniot & $31.7292^{\circ} \mathrm{N}, 72.9822^{\circ} \mathrm{E}$ & 2017 & Asterix & 4 \\
\hline & Chiniot & $31.7292^{\circ} \mathrm{N}, 72.9822^{\circ} \mathrm{E}$ & 2018 & Asterix & 4 \\
\hline & Bhawana & $31.5659^{\circ} \mathrm{N}, 72.6447^{\circ} \mathrm{E}$ & 2017 & Asterix & 4 \\
\hline & Bhawana & $31.5659^{\circ} \mathrm{N}, 72.6447^{\circ} \mathrm{E}$ & 2018 & Asterix & 4 \\
\hline & Laliyan & $31.49 .21^{\circ} \mathrm{N} 72.47 .50^{\circ} \mathrm{E}$ & 2017 & Asterix & 3 \\
\hline & Laliyan & $31.49 .21^{\circ} \mathrm{N} 72.47 .50^{\circ} \mathrm{E}$ & 2018 & Asterix & 4 \\
\hline \multirow[t]{6}{*}{ Jhang } & Jhang & $31.2781^{\circ} \mathrm{N}, 72.3317^{\circ} \mathrm{E}$ & 2017 & Burana & 4 \\
\hline & Jhang & $31.2781^{\circ} \mathrm{N}, 72.3317^{\circ} \mathrm{E}$ & 2018 & Burana & 4 \\
\hline & Shorkot & $30.8335^{\circ} \mathrm{N}, 72.0883^{\circ} \mathrm{E}$ & 2017 & Burana & 4 \\
\hline & Shorkot & $30.8335^{\circ} \mathrm{N}, 72.0883^{\circ} \mathrm{E}$ & 2018 & Burana & 4 \\
\hline & Ahmad Pur Sial & $30.4042^{\circ} \mathrm{N}, 71.4643^{\circ} \mathrm{E}$ & 2017 & Burana & 4 \\
\hline & Ahmad Pur Sial & $30.4042^{\circ} \mathrm{N}, 71.4643^{\circ} \mathrm{E}$ & 2018 & Burana & 4 \\
\hline
\end{tabular}

were maintained in long-term storage on slopes of rye A agar (Caten and Jinks 1968) in 25 -ml universal glass bottles (c. $16 \mathrm{ml}$ agar per bottle) inclined approximately at $45^{\circ}$. Isolates were sub-cultured when required for experiments by removing a section of 
Table 2 Potato-growing areas of the Punjab, Pakistan, from which Phytophthora infestans DNA samples were collected in 2019 and 2020

\begin{tabular}{llllll}
\hline District & Location name & Location & Year & Cultivar & No. of samples collected \\
\hline Khushab & Naushehra & $32.5641^{\circ} \mathrm{N}, 72.1594^{\circ} \mathrm{E}$ & 2019 & Caroda & 9 \\
Sargodha & Shahpur & $32.2878^{\circ} \mathrm{N}, 72.4288^{\circ} \mathrm{E}$ & 2019 & Caroda & 1 \\
Sahiwal & Saleem kot & $30.3708^{\circ} \mathrm{N}, 73.2397^{\circ} \mathrm{E}$ & 2019 & Mazika & 10 \\
Chiniot & Laliyan & $31.49 .21^{\circ} \mathrm{N} 72.47 .50^{\circ} \mathrm{E}$ & 2020 & Asterix & 1 \\
Jhang & Shorkot & $30.8335^{\circ} \mathrm{N}, 72.0883^{\circ} \mathrm{E}$ & 2020 & Burana & 4 \\
\hline
\end{tabular}

mycelium from the actively growing edge of a colony and transferring to a pea agar plate (Hollomon 1965).

\section{Determination of Mating Types}

The mating type of each unknown isolate was determined by dual culture on rye agar medium; a small section cut from an agar culture of the test isolate was placed approx. $2 \mathrm{~cm}$ from a similar section of a reference A1 or A2 isolate (reference isolates were provided by Professor Shan, Northwest Agriculture and Forestry University, China). After 2 weeks' incubation $\left(16-18^{\circ} \mathrm{C}\right.$ in darkness), plates were examined microscopically for oospore formation at the hyphal interfaces in the contact zone. Isolates which produced sexual oospores with the reference A1 and A2 mating type isolates were categorised as A2 and $\mathrm{A} 1$, respectively. When oospores with antheridia formed in the $\mathrm{A} 1 \times \mathrm{A} 1$ or $\mathrm{A} 2 \times \mathrm{A} 2$ paired cultures, the isolate was considered likely to be self-fertile. This was confirmed by single spore isolation and culture of the resulting isolates alone on rye agar; if oospores formed in these single cultures, the isolate was categorised as self-fertile. This was done to eliminate the possibility of mixed mating type cultures (Tian et al. 2015).

\section{Morphology of Oospores}

The micromorphology of oospores was examined microscopically; the presence of antheridia, the shape of the oogonia, the oospore diameter and the wall thickness were recorded (Mosa et al. 1989; Cohen et al. 1997).

\section{Foliar Aggressiveness Testing of Selected Phytophthora infestans Isolates from 2017 to 2018}

Isolates (104, 50 from 2017 and 54 from 2018) were selected on the basis of their pathogenicity, as reported by (Raza et al. 2019), from among the 149 collected in 2017-2018 and tested for mating type (as described above); isolates that caused lesions $\geq 1 \mathrm{~cm}$ in length were chosen for aggressiveness testing. Newly formed sporangia from cultures of each isolate on rye agar were collected by adding $10 \mathrm{~mL}$ of sterile, distilled water to each Petri dish, dislodging the sporangia using a needle. Spore suspensions were filtered through cheese cloth, and the concentration was adjusted to $4 \times 10^{4}$ sporangia/mL using a haemocytometer. The sporangia were chilled at $4{ }^{\circ} \mathrm{C}$ for $2 \mathrm{~h}$ to encourage release of zoospores for use in inoculation. 
A protocol adapted from Majeed et al. (2014) was used to assess aggressiveness. Uniform-sized leaves were harvested from 6-week-old glasshouse-grown potato plants cv. Caroda, washed with tap water and dried on tissue paper. For each isolate, three detached leaflets were placed adaxial side up in moist chambers and each leaflet was inoculated with a single drop $(15 \mu \mathrm{L})$ of the test isolate applied to the midrib. The boxes of leaflets were incubated at $18-20{ }^{\circ} \mathrm{C}$ in an illuminated incubator (12 h photoperiod) for 10 days. A completely randomised design was used.

Leaflets were assessed daily for 10 days after inoculation, and lesion area (LA), latent period (LP) and infection frequency (IF) were determined. The length and width of each lesion was measured daily using a ruler and used to calculate the LA. Leaflets were viewed under a low-power microscope to check for sporulation; the LP was defined as the time in hours after inoculation until development of sporulating lesions. The infection frequency (IF) was calculated from the percentage of infected leaflets (Carlisle et al. 2002). A composite aggressiveness index (CAI) was calculated using the formula of Montarry et al. (2007):

$$
\mathrm{CAI}=\frac{\mathrm{IF} \times \mathrm{LA}}{\mathrm{LP}}
$$

The experimental data (LA, LP, IF and CAI) were subjected to ANOVA using SPSS software v. 19. Parameter means for the two mating types were compared using Student's $t$ test.

\section{Genotyping and Genetic Analysis of Samples of $P$. infestans}

Lesions from 2019 and 2020 were genotyped using a 12-plex simple sequence repeat (SSR) assay according to published methods ( $\mathrm{Li}$ et al. 2013). Briefly, the abaxial sides of foliar lesions were pressed against FTA cards and a 3-mm disc of dried card was cut from the interface of green leaf tissue and brown lesion. The disc was washed according to the manufacturer's protocols and subjected to PCR to amplify 12 SSR loci (Li et al. 2013). After running on an ABI3730 capillary sequencer, the peak profiles were edited in GeneMapper (Applied Biosystems) version 5.0 and the profiles were exported. A data file of SSR data comprising 13_A2 samples from Pakistan (25), India (88) and Europe (12) and 2 samples each of another four clonal lineages (EU_5_A1, EU_6_A1, EU_8_A1 and EU_2_A1) was compiled and Bruvo's distances were calculated and used to generate a minimum spanning network (MSN) in poppr 2.8.5 (Kamvar et al. 2015) in R 3.6.3 (R core team 2020).

\section{Results}

\section{Mating Type}

A total of 149 isolates of $P$. infestans were obtained from samples of blighted potato leaves collected from fields in the potato-growing districts of the Punjab Province of Pakistan during 2017-2018 (Table 1). Of these isolates, 73\% were A1 mating type, $23 \%$ were A2 mating type, while 4\% were self-fertile. In 2017 and 2018, the ratio of 
A1 to A2 mating types was $76: 21$ and $70: 25$, respectively (Table 3). Isolates were obtained from six potato cultivars in total; there did not appear to be any association between mating type and cultivar as A2 isolates were obtained from all six cultivars sampled (Table 4). Just under half of the fields sampled (47\%) yielded isolates of both mating types, and self-fertile isolates were also present in three of these fields (Table 5).

\section{Micromorphology of Oospores}

Antheridia that developed in A1 $\times$ A2 paired cultures were amphigynous and varied from hemispherical to almost spherical in shape, hyaline and from $17-22 \mu \mathrm{m} \times 11-$ $14 \mu \mathrm{m}$ in size. The oogonia were nearly spherical, and their colour ranged from redorange to brown in colour. The oospores varied from brown to dark-brown in colour, and they were spherical (21-33 $\mu \mathrm{m}$ diameter) with two walls $2.3-5.3 \mu \mathrm{m}$ thick.

\section{Foliar Aggressiveness}

The three parameters of aggressiveness (LA, LP and IF) were very highly significantly $(P<0.001)$ correlated with each other and with the CAI (Table 6); the CAI was therefore used for subsequent comparisons. There were very highly significant differences in terms of CAI between individual isolates in both 2017 and 2018 (Figs. 1 and

Table 3 Mating types of Phytophthora infestans isolates from six potato-growing areas of Punjab, Pakistan, 2017-2018

\begin{tabular}{lllll}
\hline Year and district & Total number of isolates & \multicolumn{2}{l}{ Number of isolates of mating type } \\
\cline { 3 - 5 } & & A1 & A2 & Self-fertile \\
\hline 2017 & & & & \\
Khushab & 10 & 9 & 1 & 0 \\
Sargodha & 12 & 10 & 2 & 0 \\
Sahiwal & 13 & 8 & 4 & 1 \\
Okara & 14 & 7 & 6 & 1 \\
Jhang & 12 & 12 & 0 & 0 \\
Chiniot & 11 & 9 & 2 & 0 \\
Total & 72 & $55(76)^{\mathrm{a}}$ & $15(21)^{\mathrm{a}}$ & $2(3)^{\mathrm{a}}$ \\
2018 & & & & \\
Khushab & 12 & 12 & 0 & 0 \\
Sargodha & 13 & 10 & 2 & 1 \\
Sahiwal & 13 & 7 & 5 & 1 \\
Okara & 15 & 6 & 8 & 1 \\
Jhang & 12 & 10 & 2 & 0 \\
Chiniot & 12 & 9 & 2 & 1 \\
Total & 77 & $54(70)$ & $19(25)$ & $4(5)$ \\
Total 2017-2018 & 149 & $109(73)^{\mathrm{a}}$ & $34(23)^{\mathrm{a}}$ & $6(4)^{\mathrm{a}}$ \\
\hline
\end{tabular}

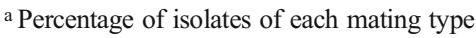


Table 4 Cultivars from which isolates of Phytophthora infestans of each mating type were obtained in potatogrowing areas of Punjab, Pakistan, 2017-2018

\begin{tabular}{lllll}
\hline \multirow{2}{*}{ District } & Number of isolates & \multicolumn{2}{l}{ Cultivar(s) yielding isolates of each mating type } \\
\cline { 4 - 5 } & & A1 & A2 & Self-fertile \\
\hline Khushab & 22 & Caroda, Barsenna & Barsenna & none \\
Sargodha & 24 & Caroda & Caroda & Caroda \\
Sahiwal & 27 & Mazika & Mazika & Mazika \\
Okara & 29 & Mazika, Sante & Mazika, Sante & Mazika \\
Jhang & 24 & Burana & Burana & none \\
Chiniot & 23 & Asterix & Asterix & Asterix \\
\hline
\end{tabular}

2), but overall, there was no significant difference in the mean CAI for the 50 isolates from 2017 (974) and for the 54 isolates from 2018 (1185). However, a tendency was noted for the more aggressive isolates to be those of the A2 mating type. Comparison of the CAIs for the A1 and A2 isolates (self-fertile isolates were excluded as only two from 2017 and four from 2018 were tested for aggressiveness) by ANOVA showed that the A2 isolates had a significantly greater mean CAI than the A1 isolates for both 2017 and 2018 isolates (Table 7).

There were no significant differences in CAI between isolates of $P$. infestans from different districts of the Punjab (Table 8). There were some significant differences between isolates obtained from different cultivars, with those from cv. Barsenna being more aggressive than those from cvs. Mazika, Caroda and Sante; this was not associated with a larger proportion of A2 isolates from this cultivar (Table 9). However, as there were only four isolates from cv. Barsenna tested for aggressiveness, this could be a sampling artefact.

Table 5 Number of fields from which A1, A2 and A1 + A2 isolates of Phytophthora infestans of each mating type were obtained in potato-growing areas of Punjab, Pakistan, 2017-2018

District Number of fields sampled Number of fields from which isolates of mating types were obtained

\begin{tabular}{lllll} 
& & A1 only & A2 only & A1 + A2 \\
\hline Khushab & 6 & 5 & 0 & 1 \\
Sargodha & 6 & $2^{*}$ & 0 & 4 \\
Sahiwal & 6 & 1 & 0 & $5^{* *}$ \\
Okara & 6 & 1 & $2 *$ & $3 *$ \\
Jhang & 6 & 5 & 0 & 1 \\
Chiniot & 6 & $3^{*}$ & 0 & 3 \\
Total & 36 & 17 & 2 & 17 \\
\hline
\end{tabular}

*One field also yielded one self-fertile isolate

**One field also yielded two self-fertile isolates 
Table 6 Correlation coefficients of the parameters of aggressiveness derived from inoculation onto detached potato leaflets of isolates of Phytophthora infestans obtained from the Punjab, Pakistan, in 2017 and 2018

\begin{tabular}{llll}
$\begin{array}{l}\text { Lesion } \\
\text { area }\left(\mathrm{mm}^{2}\right)\end{array}$ & $\begin{array}{l}\text { Latent } \\
\text { period }(\mathrm{h})\end{array}$ & $\begin{array}{l}\text { Infection } \\
\text { efficiency }(\%)\end{array}$ & $\begin{array}{l}\text { Composite } \\
\text { aggressiveness index }\end{array}$ \\
\hline
\end{tabular}

Lesion area $\left(\mathrm{mm}^{2}\right)$

1

Latent period (h)

$-0.9233 * * * \quad 1$

Infection efficiency (\%)

$0.8821 * * *-0.9288 * * * \quad 1$

Composite aggressiveness index

$0.8797 * * *$

$-0.9027 * * * \quad 0.8828 * * *$

1

$* * * P<0.001$

\section{Genotyping}

Technical problems led to the loss of the living isolates collected in 2017-2018. Genotyping of pathogen DNA from 25 lesions collected during December 2019 and January 2020 (Table 2) revealed a single multi-locus genotype (MLG). Comparisons against a large database of published (Chowdappa et al. 2013; Chowdappa et al. 2015; Dey et al. 2018; Martin et al. 2019) and unpublished SSR profiles indicated that this MLG was a sub-clonal variant of the 13_A2 clonal lineage. This single MLG was collected from five districts in Pakistan. A sample of MLGs from India and Europe was examined using poppr and the MSN demonstrated a cluster of closely related 13_A2 MLGs genetically distinct from each of the other four clonal lineages (Fig. 3). The MLG sampled in Pakistan was identical to one sampled in both India and Europe.

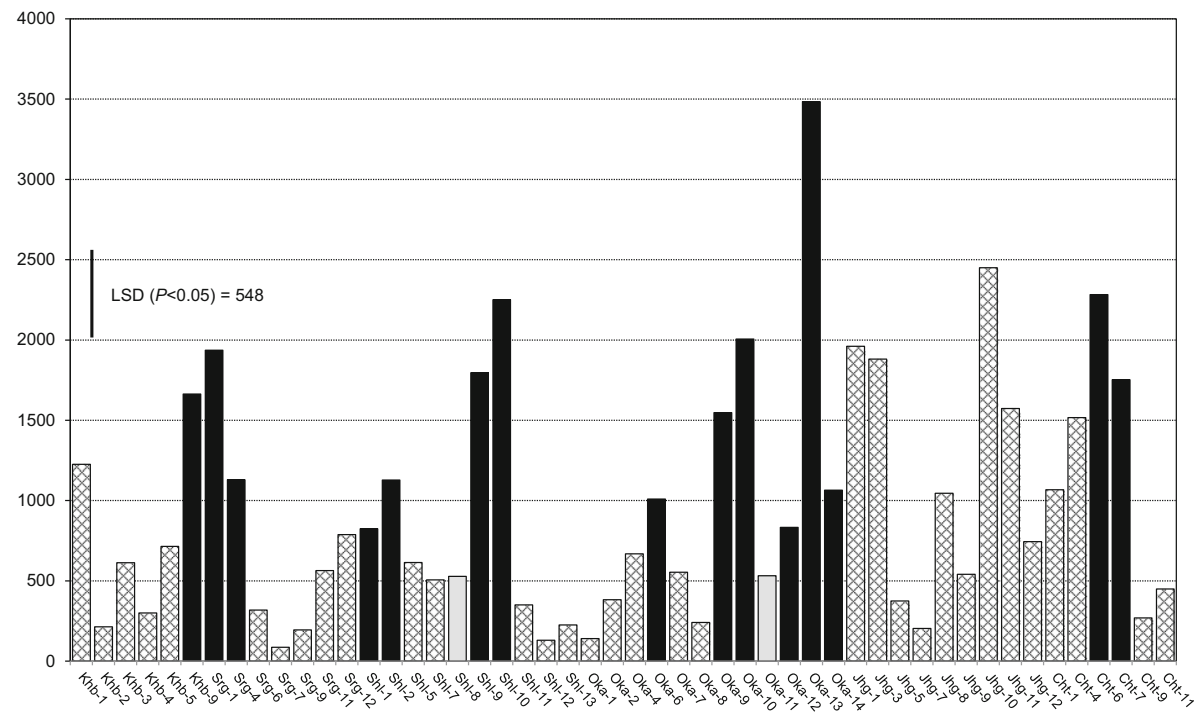

Fig. 1 Composite aggressive index (CAI) for Phytophthora infestans isolates collected in 2017 from the Punjab, Pakistan. A1 isolates are indicated by cross-hatched bars, A2 isolates by black bars and self-fertile isolates by grey bars 


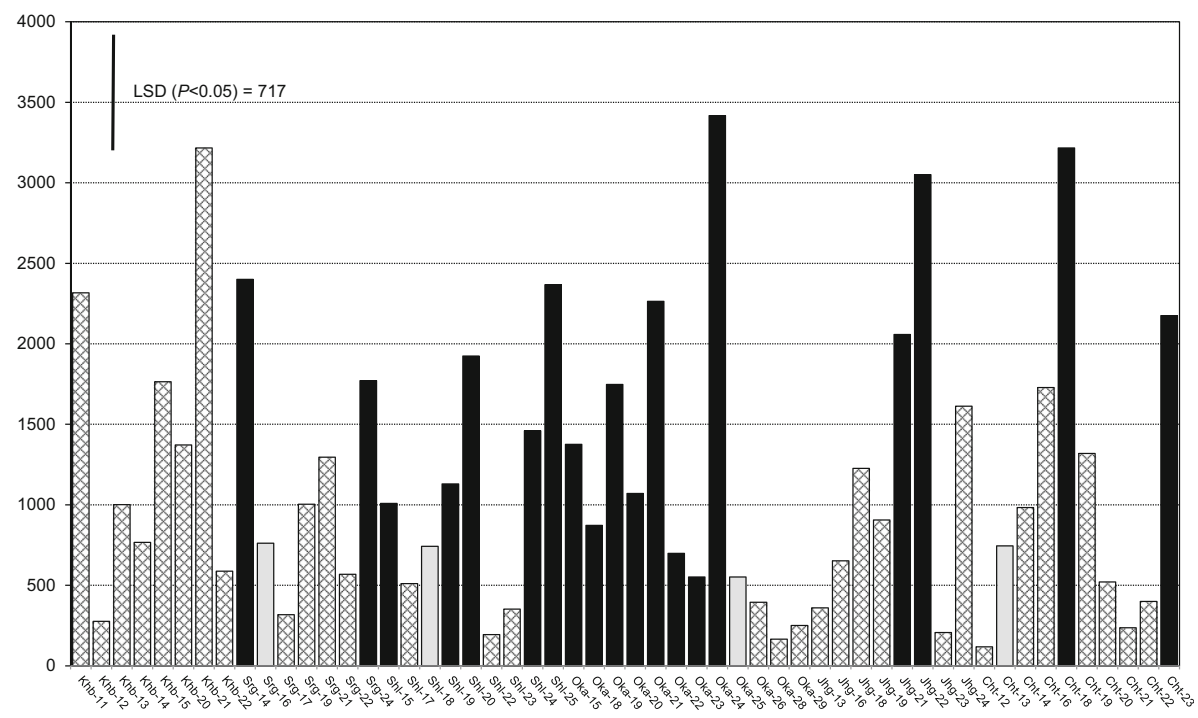

Fig. 2 Composite aggressive index (CAI) for Phytophthora infestans isolates collected in 2018 from the Punjab, Pakistan. A1 isolates are indicated by cross-hatched bars, A2 isolates by black bars and self-fertile isolates by grey bars

\section{Discussion}

The oospores observed in this study, when isolates were crossed with the opposite mating type, were spherical and had 21-33 $\mu \mathrm{m}$ diameter, which is similar in size to those reported by others; Erwin and Ribeiro (1996) state that in culture oospores' diameters range from 24 to $56 \mu \mathrm{m}$, while Gallegly and Hong (2008) give a figure of about $30 \mu \mathrm{m}$ as the mean oospore diameter. Singh et al. (1994) reported that they obtained slightly larger oospores (32-44 $\mu \mathrm{m}$ diameter) when A2 P. infestans isolates from India were paired in culture with an A1 isolate of Phytophthora capsici.

In the present study, both mating types of $P$. infestans were found to occur in all six districts of the Punjab, Pakistan, from which isolates were obtained either in 2017 or in 2018. However, in every case, the A1 mating type predominated, and overall, $73 \%$ of isolates were A1. In the districts of Jhang and Khushab, only A1 isolates were detected in 2017 and 2018, respectively. In contrast, recent studies in India showed exclusively

Table 7 Comparison of composite aggressiveness indices for A1 and A2 isolates of Phytophthora infestans obtained from the Punjab, Pakistan, in 2017 and 2018

\begin{tabular}{llll}
\hline Year of isolate collection & \multicolumn{2}{c}{ Mean CAI } & \multirow{2}{*}{ Significance } \\
\cline { 2 - 3 } & A1 only & A2 only & \\
\hline 2017 & 694 & 1647 & $* * *$ \\
2018 & 859 & 1819 & $* * *$ \\
2017 and 2018 & 774 & 1743 & $* * *$ \\
\hline
\end{tabular}

$* * * P<0.001$ 
Table 8 Comparison of composite aggressiveness indices for isolates of Phytophthora infestans obtained from six districts of the Punjab, Pakistan, in 2017 and 2018

\begin{tabular}{llll}
\hline District & Number of isolates & A2 isolates $(\%)$ & Mean CAI* \\
\hline Khushab & 14 & 7 & 1145 \\
Sargodha & 14 & 29 & 938 \\
Sahiwal & 19 & 47 & 949 \\
Okara & 24 & 58 & 1076 \\
Jhang & 17 & 12 & 1226 \\
Chiniot & 16 & 25 & 1174 \\
Total/mean & 104 & 33 & 1085 \\
\hline
\end{tabular}

*There were no significant differences $(P>0.05)$ between CAIs for isolates from the six sampled districts of the Punjab

A2 populations of the aggressive European 13_A2 genotype in southern India on potato and tomato during 2010-2012 (Chowdappa et al. 2015) and in eastern and north-eastern India on potato and tomato during 2012-2014 (Dey et al. 2018). Published studies of the $P$. infestans population on potatoes in north-west India appear to be lacking. Genotype 13_A2 is reported to be widespread in Bangladesh (Kessel et al. 2017) and has also been found in Nepal (Sharma Adhikari 2017). When genotype 13_A2 is initially introduced into a region, it tends to displace the existing $P$. infestans population, often rapidly (Cooke et al. 2012). The predominance of the A1 mating type of $P$. infestans found in the present study in the Punjab, Pakistan, in 2017-2018 suggests that genotype 13_A2, detected in 2019-2020, has only recently been introduced.

Aggressiveness, defined as the quantity of disease induced by a pathogenic strain on a susceptible host (Andrivon 1993) is often invoked to explain changes in P. infestans populations. In reality, pathogenic fitness (the expected contribution of a phenotype to the subsequent generation; Antonovics and Alexander 1989), of which aggressiveness is only one aspect, is of greater epidemiological significance. However, while fitness is environmentally dependent and difficult to measure, one of the attributes of

Table 9 Comparison of composite aggressiveness indices for isolates of Phytophthora infestans obtained from six different potato cultivars in the Punjab, Pakistan, in 2017 and 2018

\begin{tabular}{llll}
\hline Cultivar & Number of isolates & A2 isolates $(\%)$ & Mean CAI* \\
\hline Asterix & 16 & 25 & $1174 \mathrm{ab}$ \\
Barsenna & 4 & 25 & $1710 \mathrm{a}$ \\
Burana & 17 & 12 & $1226 \mathrm{ab}$ \\
Caroda & 24 & 17 & $930 \mathrm{~b}$ \\
Mazika & 31 & 52 & $1059 \mathrm{~b}$ \\
Sante & 12 & 58 & $919 \mathrm{~b}$ \\
Total/mean & 104 & 33 & 1170
\end{tabular}

*CAIs for isolates from the sampled cultivars followed by the same letter are not significantly different $(P<0.05)$ 


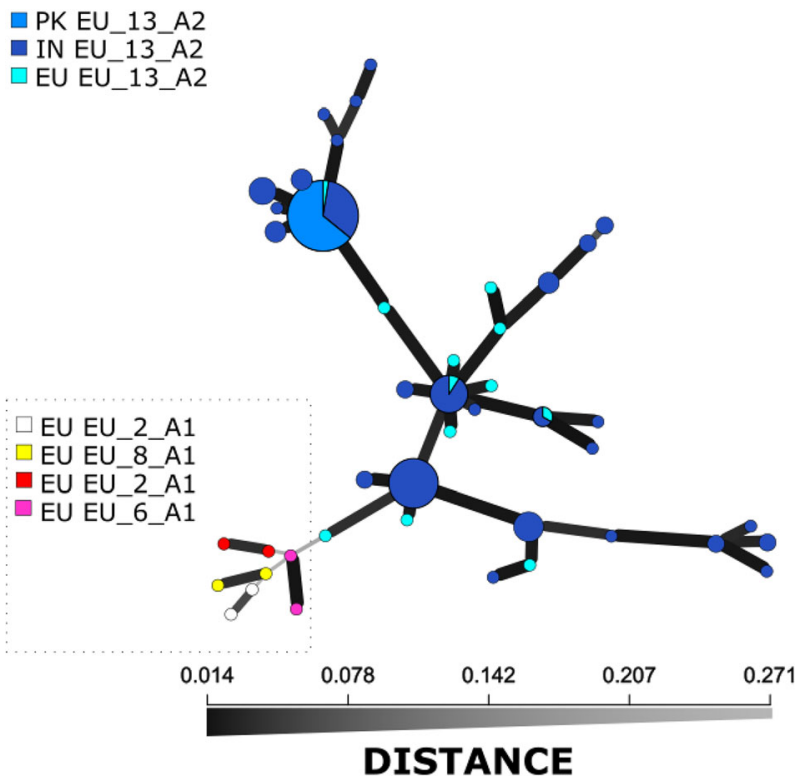

Fig. 3 Minimum spanning network (MSN) of samples of Phytophthora infestans DNA collected from Pakistan, India and Europe. Each node represents an MLG with edge width and shading reflecting genetic relatedness based on Bruvo's genetic distance. This MSN indicates a cluster of clonal MLG variants of EU_13_A2 that are genetically closely related in comparison with the more genetically distinct pairs of isolates of other clonal lineages. The latter clones are delineated within the dashed line

aggressiveness is that it can be measured under standard conditions allowing comparison between isolates (Andrivon 1993). Studies of $P$. infestans have therefore frequently focussed on aggressiveness in order to try to understand the behaviour of components of populations of the pathogen (e.g. Carlisle et al. 2002).

In the present study, the foliar aggressiveness of all isolates collected in 2017 and 2018, except for the 45 which were only weakly pathogenic (which were all of the A1 mating type), was evaluated and this was done using detached potato leaflets. Although this technique does not completely mimic infection in the field, it allows for the comparison of substantial numbers of isolates under controlled conditions and is therefore widely used (e.g. Majeed et al. 2014). Because the components of aggressiveness (latent period, lesion area and infection frequency) measured in the present study were closely correlated, a composite aggressiveness index (CAI) was calculated and used to compare the isolates. Majeed et al. (2014), in their study using 10 isolates of $P$. infestans collected in the Khyber Pakhtunkhwa Province of Pakistan in 2011, defined isolates possessing a CAI of 1000 or greater as being highly aggressive and reported that $40 \%$ of their isolates belonged to this class. In the present study of 104 isolates from the Punjab, 46\% possessed CAIs of 1000 or more. However, as different cultivars were used (cv. Desiree by Majeed et al. 2014 and cv. Caroda in the present study) and only a small number of isolates were evaluated in the earlier study, the results may not be strictly comparable. The most striking finding in terms of aggressiveness in the present study was that, overall, isolates of the A2 mating type had a very highly significantly greater CAI than A1 isolates. While some individual A1 isolates were also highly aggressive, others were only weakly aggressive $(\mathrm{CAI}<500)$, whereas no A2 isolates fell into the weakly aggressive class. Nonetheless, within some fields, aggressive 
isolates of both mating types occurred together. It should be emphasised that there is no genetic link between aggressiveness and mating type of $P$. infestans; because of its clonal reproduction, strong associations between mating type and phenotypic characters such as aggressiveness and fungicide resistance can arise in particular places and times, but this is a result of selection of specific genotypes. The generally greater aggressiveness of A2 compared with A1 isolates is most probably an effect of the particular A2 genotype(s) of the pathogen present in the Punjab. Such an association, as noted above, occurred in the case of the aggressive genotype 13_A2 (Cooke et al. 2012). The finding of only the 13_A2 type in each of 25 samples from five districts of the Punjab Region in Pakistan collected in 2019 2020 (Fig. 3) suggests that this lineage, which has not previously been reported from Pakistan, is widely distributed. This supports the premise that the greater aggressiveness of the A2 isolates obtained in 2017-2018 might be because they belong to the 13_A2 genotype, recently introduced to Pakistan. Unfortunately, it was not possible to genotype the 2017-2018 isolates themselves.

The occurrence of both mating types within a single field in 17 cases indicated a potential for sexual reproduction by $P$. infestans. There could be a risk of oospore-derived infections in such fields (Widmark et al. 2007), which could lead to earlier attacks and more diverse pathogen populations as has been reported from the Nordic countries (Hannukkala et al. 2007; Brurberg et al. 2011). It is therefore important that, as well as using fungicides to prevent pathogen infection and, where possible, growing potato cultivars with some resistance to late blight, growers should avoid continuous cropping, which increases the risk of infection by soil-borne oospores and may cause earlier attacks (Runno-Paurson et al. 2009). Turkensteen et al. (2000) showed that oospores can survive in field soil for up to 4 years, so using rotations with 5 or more years between potato crops should reduce this risk.

Acknowledgements The authors are thankful to the Higher Education Commission, Islamabad, Pakistan, for funding the project 204448/NRPU/R\&D/HEC/14/1074, which supported this work in the Department of Plant Pathology, College of Agriculture, University of Sargodha, Sargodha. Professor Shan (Northwest Agriculture and Forestry University, China) is thanked for kindly providing the reference A1 and A2 isolates of $P$. infestans used in the mating type tests.

Funding Information David Cooke and Louise Sullivan received funding from the Rural and Environment Science and Analytical Services Division of the Scottish Government.

Open Access This article is licensed under a Creative Commons Attribution 4.0 International License, which permits use, sharing, adaptation, distribution and reproduction in any medium or format, as long as you give appropriate credit to the original author(s) and the source, provide a link to the Creative Commons licence, and indicate if changes were made. The images or other third party material in this article are included in the article's Creative Commons licence, unless indicated otherwise in a credit line to the material. If material is not included in the article's Creative Commons licence and your intended use is not permitted by statutory regulation or exceeds the permitted use, you will need to obtain permission directly from the copyright holder. To view a copy of this licence, visit http://creativecommons.org/licenses/by/4.0/.

\section{References}

Ahmad I, Mirza JI (1995) Occurrence of A2 mating type of Phytophthora infestans in Pakistan. Research and development of potato production in Pakistan. Proceedings of the National Seminar held at NARC, Islamabad, Pakistan 23-25 April, 1995. pp.189-196 
Ahmad I, Batool S, Mirza JI (2002) Distribution of mating types of Phytophthora infestans in Pakistan. Proceedings GILB '02 Conference: Managing the global threat, 11-13 July 2002, Hamburg, 129-130

Ahmad I, Raza G, Iram S (2008) Phenotypic markers of Phytophthora infestans. Arch Phytopathol Pflanzenschutz 41:104-112

Andrivon D (1993) Nomenclature for pathogenicity and virulence: the need for precision. Phytopathology 83 : 889-890

Antonovics J, Alexander HM (1989) The concept of fitness in plant-fungal pathogen systems. In: Leonard KJ, Fry WE (eds) Plant disease epidemiology (volume 2). McGraw-Hill Publishing Company, New York, pp $185-214$

Brurberg MB, Elameen A, Le VH, Nærtsad R, Hermansen A, Lehtinen A, Hannukkala A, Nielsen B, Hansen J, Andersson B, Yuen J (2011) Genetic analysis of Phytophthora infestans populations in the Nordic European countries reveals high genetic diversity. Fungal Biol 115:335-342

Burlingame B, Mouillé B, Charrondière R (2009) Nutrients, bioactive non-nutrients and anti-nutrients in potatoes. J Food Compos Anal 22:494-502

Carlisle DJ, Cooke LR, Watson S, Brown AE (2002) Foliar aggressiveness of Northern Ireland isolates of Phytophthora infestans on detached leaflets of three potato cultivars. Plant Pathol 51:424-434

Caten CE, Jinks J (1968) Spontaneous variability of single isolates of Phytophthora infestans. I. Cultural variation. Can J Bot 46:329-348

Chowdappa P, Kumar NBJ, Madhura S, Kumar MSP, Myers KL, Fry WE, Squires JN, Cooke DEL (2013) Emergence of 13_A2 blue lineage of Phytophthora infestans was responsible for severe outbreaks of late blight on tomato in south-west India. J Phytopathol 161:49-58

Chowdappa P, Nirmal Kumar BJ, Madhura S, Mohan Kumar SP, Myers KL, Fry WE, Cooke DEL (2015) Severe outbreaks of late blight on potato and tomato in South India caused by recent changes in the Phytophthora infestans population. Plant Pathol 64:191-199

Cohen Y, Farkash S, Reshit Z, Baider A (1997) Oospore production of Phytophthora infestans in potato and tomato leaves. Phytopathology 87:191-196

Cooke DEL, Cano LM, Raffaele S, Bain RA, Cooke LR, Etherington GJ, Deahl KL, Farrer RA, Gilroy EM, Goss EM, Grünwald NJ, Hein I, MacLean D, McNicol JW, Randall E, Oliva RF, Pel MA, Shaw DS, Squires JN, Taylor MC, Vleeshouwers VGAA, Birch PRJ, Lees AK, Kamoun S (2012) Genome analyses of an aggressive and invasive lineage of the Irish potato famine pathogen. PLoS Pathog 8:e1002940

Dey T, Saville A, Myers K, Tewari S, Cooke DEL, Tripathy S, Fry WE, Ristaino JB, Guha Roy S (2018) Large subclonal variation in Phytophthora infestans from recent severe late blight epidemics in India. Sci Rep 8:4429

Drenth A, Turkensteen LJ, Govers F (1993) The occurrence of the A2 mating type of Phytophthora infestans in the Netherlands-significance and consequences. Eur J Plant Pathol 99(Suppl 3):57-67

Erwin DC, Ribeiro OK (1996) Phytophthora diseases worldwide. Chapter 33: Phytophthora infestans (Mont.) de Bary (1876). APS press, St Paul, pp 346-353

Fernández-Northcote EN, Navia O, Gandarillas A (2000) Basis of strategies for chemical control of potato late blight developed by PROINPA in Bolivia. Fitopatología 35:137-149

Fry WE (2008) Phytophthora infestans: the plant (and R gene) destroyer. Mol Plant Pathol 9:385-402

Fry WE, Birch PRJ, Judelson HS, Grünwald NJ, Danies G, Everts KL, Gevens AJ, Gugino BK, Johnson DA, Johnson SB, McGrath MT, Myers KL, Ristaino JB, Roberts PD, Secor G, Smart CD (2015) Five reasons to consider Phytophthora infestans a reemerging pathogen. Phytopathology 105:966-981

Gallegly ME, Galindo J (1958) Mating types and oospores of Phytophthora infestans in nature in Mexico. Phytopathology 48:274-277

Gallegly ME, Hong C (2008) Phytophthora: identifying species by morphology and DNA fingerprints. APS Press, St Paul, pp 76-77

Ghorbani R, Wilcockson SJ, Giotis C, Leifert C (2004) Potato late blight management in organic agriculture. Outlooks Pest Manag 15:176-180

Hannukkala AO, Kaukoranta T, Lehtinen A, Rakhonen A (2007) Late-blight epidemics on potato in Finland, 1933-2002; increased and earlier occurrence of epidemics associated with climate change and lack of rotation. Plant Pathol 56:167-176

Hijmans RJ (2001) Global distribution of the potato crop. Am J Potato Res 78:403-412

Hohl HR, Iselin K (1984) Strains of Phytophthora infestans from Switzerland with A2 mating type behaviour. Trans Br Mycol Soc 83:529-530

Hollomon DW (1965) A medium for the direct isolation of Phytophthora infestans. Plant Pathol 14:34-35

Jansky S, Navarre R, Bamberg J (2019) Introduction to the special issue on the nutritional value of potato. Potato Res 96:95-97

Kamvar ZN, Brooks JC, Grunwald NJ (2015) Novel R tools for analysis of genome-wide population genetic data with emphasis on clonality. Front Genet 6:208 
Kessel G, Moene A, van Valkengoed E, van der Voet P, Michielsen JM, Ahsan H, Schmelzer T, Maroof M, Syed A (2017) Geodata to control potato late blight in Bangladesh. PAGV - Special Report 18:59-60

Khan BA, Haq I, Iftikhar S, Aslam M (1985) Occurrence of the late blight of potatoes in Pakistan. Pak J Bot $17: 163$

Li Y, Cooke DEL, Jacobsen E, van der Lee T (2013) Efficient multiplex simple sequence repeat genotyping of the oomycete plant pathogen Phytophthora infestans. J Microbiol Methods 92:316-322

Majeed A, Chaudhry Z, Muhammad Z (2014) Variation in aggressiveness of Phytophthora infestans pathotypes collected from different potato fields of Khyber Pakhtunkhwa (Pakistan). Int J Agric Biol 16:807-812

Martin FN, Zhang Y, Cooke DEL, Coffey MD, Grunwald NJ, Fry WE (2019) Insights into evolving global populations of Phytophthora infestans via new complementary mtDNA haplotype markers and nuclear SSRs. PLoS One 14:e0208606

Montarry J, Corbiere R, Andrivon D (2007) Is there a trade-off between aggressiveness and overwinter survival in Phytophthora infestans? Funct Ecol 21:603-610

Mosa AA, Kato M, Sato N, Kobayashi K, Ogoshi A (1989) Occurrence of the A2 mating type of Phytophthora infestans on potato in Japan. Jpn J Phytopathol 55:615-620

Nowicki M, Foolad MR, Nowakowska M, Kozik EU (2012) Potato and tomato late blight caused by Phytophthora infestans: an overview of pathology and resistance breeding. Plant Dis 96:4-17

Pakistan Economic Survey 2018-19 (2019) Economic adviser's wing, Finance Division, Government of Pakistan, Islamabad, finance.gov.pk/survey/chapters_19/Economic_Survey_2018_19.pdf. Accessed 13 Aug 2019

R Core Team (2020) R: A language and environment for statistical computing. R Foundation for Statistical Computing, Vienna URL http://www.R-project.org/. Accessed 10 June 2020

Raza W, Ghazanfar MU, Hamid MI (2019) Pathotype determination of Phytophthora infestans isolates on detached potato leaves under laboratory conditions. Int J Bot Studies 4:7-12

Runno-Paurson E, Fry WE, Myers KL, Koppel M, Mänd M (2009) Characterization of Phytophthora infestans isolates collected from potato in Estonia during 2002-2003. Eur J Plant Pathol 124:565-575

Sharma Adhikari BP (2017) Genetic diversity of potato late bight in Nepal. LAP Lambert Academic Publishing, $196 \mathrm{pp}$

Singh BP, Roy S, Bhattacharyya SK (1994) Occurrence of the A2 mating type of Phytophthora infestans in India. Potato Res 37:227-231

Tian YE, Yin JL, Sun JP, Ma YF, Wang QH, Quan JL, Shan WX (2015) Dominance of a single clonal lineage in the Phytophthora infestans population from northern Shaanxi, China revealed by genetic and phenotypic diversity analysis. Plant Pathol 64:200-2006

Turkensteen LJ, Flier WJ, Wanningen R, Mulder A (2000) Production, survival and infectivity of oospores of Phytophthora infestans. Plant Pathol 49:688-696

Widmark A-K, Andersson B, Cassel-Lundhagen A, Sandström M, Yuen JE (2007) Phytophthora infestans in a single field in Southwest Sweden early in spring: symptoms, spatial distribution and genotypic variation. Plant Pathol 56:573-579

Wijesinha-Bettoni R, Mouillé B (2019) The contribution of potatoes to global food security, nutrition and healthy diets. Am J Potato Res 96:139-149

Yuen JE, Andersson B (2013) What is the evidence for sexual reproduction of Phytophthora infestans in Europe? Plant Pathol 62:485-491

Publisher's Note Springer Nature remains neutral with regard to jurisdictional claims in published maps and institutional affiliations.

\section{Affiliations}

\section{Waqas Raza ${ }^{1}$ - Muhammad Usman Ghazanfar ${ }^{1}$ - Louise Sullivan ${ }^{2}$ • David E. L. Cooke $^{2} \cdot$ Louise R. Cooke ${ }^{3}$}

1 Department of Plant Pathology, College of Agriculture, University of Sargodha, Sargodha, Pakistan

2 Cell and Molecular Sciences, The James Hutton Institute, Invergowrie, Dundee DD2 5DA, UK

3 School of Biological Sciences, Queen's University Belfast, Belfast, Northern Ireland, UK 